\title{
PENGARUH PEMBERIAN KURMA TERHADAP KEMAJUAN PERSALINAN KALA II IBU BERSALIN DI RUMAH SAKIT AURA SYIFA KABUPATEN KEDIRI
}

\author{
Lely Ayu Permata Addini ${ }^{1}$, Ira Titisari ${ }^{2}$, Ribut Eko Wijanti ${ }^{3}$ \\ 1,2,3 Poltekkes Kemenkes Malang Prodi Kebidanan Kediri, Jl.KH Wachid Hasyim \\ No.64B, Kediri \\ e-mail : lelyayupermata@gmail.com
}

DOI : https://doi.org/10.35451/jkk.v2i2.340

\begin{abstract}
Progress of labor depends on three factors: (power) is the efficiency of uterine contractions, passenger (fetal) and passage (uterus, cervix, pelvis). When there are any abnormalities in one or more of the factors above it can slow the progress of delivery process. Dates rich in carbohydrates as a source of energy, affect the progress of labor, spontaneity in labor and reduce postpartum hemorrhage. Carbohydrates as a booster are sugars that are absorbed and used by body cells not long after consumed. The purpose of this study was to determine the effect of dates on the progress of the second stage of labor in Aura Syifa Hospital Kediri Regency. The research design used was pre-experimental (pre experimental design) with a static group approach (the static group comparison). The samples were 32 respondents who were determined by accidental sampling technique. In this research the data analysis used was Fisher Exact Probability test. Based on the statistic test result that there was no influence of Providing Date Palm to the mother in labor at second progress of labor in Kediri Aura Syifa Hospital.
\end{abstract}

Keywords: Date Palm, The Second Stage Of Labor, Child Birth

\section{Pendahuluan}

Angka Kematian Ibu (AKI) merupakan salah satu indikator untuk menentukan gambaran derajat kesehatan masyarakat. Menurut World Health Organization (WHO) pada tahun 2013 menyebutkan bahwa AKI di dunia sebesar 210 per 100.000 kelahiran hidup. Hasil Survey Demografi dan Kesehatan Indonesia (SDKI) pada tahun 2012 sebesar 359 per 100.000 kelahiran hidup. Hal ini menunjukkan bahwa AKI di Indonesia masih tinggi dibanding negara anggota Association of Southeast
Asian Nations (ASEAN) lainnya (Buku Ajar Kesehatan Ibu Dan Anak, 2015).

Di Jawa Timur, tahun 2014 AKI mencapai 93,52 per 100.000 kelahiran hidup. Di Kabupaten Kediri AKI berhasil mengalami penurunan dari tahun 2013 sebesar 34 menjadi 17 di tahun 2014. Penyebab kematian ibu disebabkan karena Preeklampsi, Preeklampsi berat, perdarahan dan Jantung (Profil Kesehatan Kabupaten Kediri, 2014).

Persalinan dinggap normal apabila ibu dan janin tidak mengalami komplikasi yang menyertai. Persalinan merupakan suatu proses alamiah 
yang dialami oleh setiap wanita hamil, dengan lamanya kehamilan normal dihitung dari hari pertama haid terakhir. Kehamilan dibagi menjadi 3 trimester yaitu pada trimester pertama (minggu ke 1-12), trimester kedua (minggu ke 13-27) dan trimester ketiga (minggu ke 28-40). Pada proses persalinan ini diawali dengan membuka serta menipisnya serviks, pengeluaran janin dan plasenta dari jalan lahir ibu. Pada proses ini membutuhkan persiapan fisik dan emosional yang cukup (Saifuddin, A.B, 2009).

Bagi sebagian wanita yang tidak memiliki cukup pengetahuan dan kesiapan dalam menghadapi proses persalinan akan kehilangan kendali akibat timbulnya kontraksi ringan ataupun kontraksi hebat sehingga ibu menunjukkan perilaku seperti menangis atau gerakan tak terkendali saat di tempat tidur akibat dari kontraksi yang ringan tersebut (Padila, 2014).

Perasaan takut, nyeri, kecemasan dan rasa tidak aman yang disebabkan oleh lingkungan dan orang baru di sekitarnya dapat memicu pelepasan catecholamin sehingga mengganggu kemajuan persalinan. Psikologi ibu yang terganggu dapat mempengaruhi kemajuan persalinan. Hal ini juga dapat menimbulkan stress pada ibu, akibatnya terjadi pengeluaran adrenalin sehingga pembuluh darah menyempit dan mengurangi aliran darah yang membawa oksigen ke rahim. Akibatnya, terjadi penurunan kontraksi rahim yang memanjang pada waktu persalinan (Padila, 2014).

Pada persalinan normal, berlangsung selama 18 jam tanpa diikuti adanya komplikasi dari ibu maupun janin. Persalinan dibagi menjadi 4 kala, pada kala I dimulai saat awal persalinan sampai pembukaan lengkap $(10 \mathrm{~cm})$ yang terbagi menjadi dua fase yakni laten (8 jam) dan aktif (7 jam), pada kala II yakni pembukaan lengkap sampai bayi lahir, pada kala III bayi lahir sampai lahirnya plasenta dan kala IV yakni lahirnya plasenta sampai 2 jam setelah persalinan berlangsung (Saifuddin, A.B, 2009).

Persalinan

yang sesungguhnya, ditandai dengan adanya gejala seperti penipisan dan pembukaan serviks, adanya kontraksi yang mengakibatkan serviks berubah dan keluarnya cairan lendir bercampur darah melalui jalan lahir (JNPK-KR, 2008). Kemajuan persalinan bergantung pada tiga faktor yaitu power (kekuatan) adalah efisiensi kontraksi uterus, passenger (janin) dan passage (uterus, serviks, tulang panggul). Apabila terjadi ketidaknormalan pada salah satu atau lebih dari faktor diatas dapat memperlambat kemajuan pada proses persalinan (Holmes, D \& Baker, N, 2011).

Kordi et.al (2014) dalam penelitiannya menunjukkan bahwa kurma kaya akan karbohidrat sebagai sumber tenaga, mempengaruhi kemajuan persalinan, spontanitas dalam persalinan dan mengurangi perdarahan postpartum. Karbohidrat sebagai penguat ini adalah gula yang diserap dan digunakan oleh sel tubuh tidak lama setelah dikonsumsi. Kurma juga mengandung vitamin $B$, mineral, besi, kalsium, magnesium, kalium, asam lemak jenuh dan asam lemak tak jenuh. Asam lemak selain menghasilkan energi juga membantu menyediakan prostaglandin. Asam lemak dapat membantu menyimpan energi dan memperkuat otot-otot rahim. Kurma juga mengandung hormon yang dapat meregangkan rahim ketika menjelang kelahiran bayi (JMRH, 2014). 
Direktur Jendral British Nutrition Foundation, meneliti keunggulan buah kurma yang mengandung berbagai vitamin dan mineral penting seperti vitamin $A$, tiamin, riboflavin, niasin dan kalium dalam jumlah yang ideal. Kandungan yang tinggi pada kurma sangat menguntungkan jantung dan pembuluh darah. Denyut nadi menjadi semakin teratur dan otot-otot menjadi kontraksi sehingga membantu menstabilkan tekanan darah, tentunya ini sangat baik pada saat proses persalinan karena dapat disimpulkan bahwa kurma mencegah penyakit hipertensi. Selain kalium yang berfungsi untuk kesehatan jantung dan pembuluh darah kurma juga mengandung salisilat dan sumber gula yang sangat tinggi sehingga bermanfaat bagi ibu yang sedang melahirkan (Nugraheni, 2015).

Buah kurma basah (ruthab) mempunyai pengaruh mengontrol laju gerak rahim dan menambah masa systole (kontraksi jantung ketika darah dipompa ke pembuluh nadi). Dengan mengkonsumsi kurma ketika menjelang persalinan, selain mengenyangkan juga bermanfaat membuat gerakan kontraksi rahim bertambah teratur, sehingga memudahkan dalam proses persalinan. Sedangkan Tamr (kurma kering) berfungsi untuk menguatkan sel-sel usus dan dapat membantu melancarkan saluran kencing karena mengandung serabut-serabut yang bertugas mengontrol laju gerak usus dan menguatkan rahim terutama pada saat akan melahirkan. (Rahmawan, Zaki. 2005)

Hasil Studi Pendahuluan yang dilakukan di Rumah Sakit Aura Syifa pada bulan Oktober-Desember 2016 didapatkan jumlah persalinan sebanyak 449 kasus yang berakhir dengan persalinan normal sebanyak 76 kasus dan 234 kasus berakhir dengan Secsio caesarea dan 139 persalinan dengan lain-lain. Angka kejadian prolong kala II dari bulan Januari-Desember tahun 2016 di Rumah Sakit Aura Syifa sebanyak 74 kasus berakhir dengan persalinan spontan dan Secsio caesarea. Berdasarkan uraian diatas maka penulis tertarik untuk melakukan penelitian dengan judul "Pengaruh Pemberian Kurma terhadap Kemajuan Persalinan Kala II Ibu bersalin di Rumah Sakit Aura Syifa Kabupaten Kediri".

\section{METODE}

Desain penelitian ini adalah
desain pra-eksperimental (pre pendekatan perbandingan kelompok statis. Populasi dalam penelitian ini adalah seluruh ibu bersalin yang melakukan persalinan di RS Aura Syifa. Sampel penelitian ini sebanyak 32 ibu bersalin yang terbagi menjadi 16 kelompok perlakuan dan 16 kelompok kontrol. Teknik sampling yang digunakan yakni accidental sampling.

\section{HASIL PENELITIAN}

Tabel 1. Kemajuan Persalinan Kala II yang Diberi Kurma

\begin{tabular}{lcc}
\hline $\begin{array}{l}\text { Kelompok } \\
\text { Perlakuan }\end{array}$ & $\mathrm{F}$ & $\%$ \\
\hline Normal & 16 & 100 \\
\hline Tidak Normal & 0 & 0 \\
\hline Jumlah & 16 & 100
\end{tabular}

(Sumber : Data primer hasil penelitian bulan Juli-Agustus 2017)

Berdasarkan tabel 1 diatas diketahui seluruh responden (100\%) kelompok perlakuan diberikan kurma sebanyak 100 gram dan diketahui hasil kemajuan persalinan pada kala II normal. 
Tabel 2. Kemajuan Persalinan Kala II Tanpa Diberi Kurma

\begin{tabular}{lcc}
\hline $\begin{array}{l}\text { Kelompok } \\
\text { Kontrol }\end{array}$ & $\mathrm{F}$ & $\%$ \\
\hline Normal & 13 & 81,25 \\
\hline Tidak Normal & 3 & 18,75 \\
\hline Jumlah & 16 & 100 \\
\hline
\end{tabular}

(Sumber : Data primer hasil penelitian bulan Juli-Agustus 2017)

Berdasarkan tabel 2 diatas diketahui bahwa hampir seluruh responden mengalami kemajuan persalinan normal berjumlah $(81,25 \%)$ dan sebagian kecil responden mengalami kemajuan persalinan tidak normal dengan jumlah $(18,75 \%)$.

\section{Tabel 3. Pengaruh Kurma Terhadap Kemajuan Persalinan Kala II Ibu Bersalin}

\begin{tabular}{lccc}
\hline \multirow{2}{*}{$\begin{array}{c}\text { Pengaruh } \\
\text { Kurma }\end{array}$} & \multicolumn{2}{c}{ Kemajuan } \\
\cline { 2 - 3 } & $\begin{array}{c}\text { kala II } \\
\text { mal }\end{array}$ & $\begin{array}{c}\text { Tidak } \\
\text { Normal }\end{array}$ & \\
\hline $\begin{array}{l}\text { Diberi } \\
\text { Kurma }\end{array}$ & 16 & 0 & 16 \\
$\begin{array}{l}\text { Tidak } \\
\text { diberi }\end{array}$ & 13 & 3 & 16 \\
$\begin{array}{l}\text { Kurma } \\
\text { Jumlah }\end{array}$ & 29 & 3 & 32 \\
\hline
\end{tabular}

(Sumber : Data primer hasil penelitian bulan Juli-Agustus 2017)

Berdasarkan Tabel 3 diatas menunjukkan bahwa nilai harapan setiap kategori pada setiap sel tidak boleh $<1$, dan $>20 \%$ jumlah kategori yang ada memiliki nilai harapan $<5$, sehingga Uji statistik menggunakan $U j \mathrm{ji}$ Chi Square $\left(X^{2}\right)$ tidak memenuhi syarat.

Berdasarkan hasil Uji Fisher Exact Probability Test di dapatkan hasil $\rho$ hitung sebesar 0,1129 dengan taraf signifikasi (a) 0,05 sehingga $\rho 0,1129$ $>0,05$ maka $\mathrm{H}_{1}$ ditolak dan $\mathrm{H}_{0}$ diterima maka tidak ada pengaruh pemberian kurma terhadap kemajuan persalinan Kala II ibu bersalin di Rumah Sakit Aura Syifa Kabupaten Kediri.

\section{PEMBahasan}

\section{Kemajuan Persalinan Kala II Ibu Bersalin yang Diberi Kurma Di Rumah Sakit Aura Syifa Kabupaten Kediri}

Berdasarkan data yang diperoleh dari hasil penelitian dapat diketahui bahwa sebanyak 16 responden ibu bersalin diberikan kurma sebanyak 100 gram diketahui semuanya mengalami kemajuan persalinan kala II normal. Hal ini tentunya juga didukung oleh beberapa faktor yang mendukung proses persalinan pada kala II selain dari faktor tenaga (power).

Pada penelitian ini faktor yang mempengaruhi antara lain yakni : peran penolong dalam membantu proses persalinan kala II, psikologi ibu yang merasakan gembira menanti proses kelahiran janin sehingga ibu menjadi semangat menghadapi proses persalinan dan didukung oleh keluarga atau suami yang mendampingi selama proses melahirkan. (Power) yang dimiliki ibu tentunya diperoleh dari asupan makanan yang dikonsumsi selama proses persalinan berlangsung, ditambah dengan kurma yang dikonsumsi pada saat fase pembukaan dan didukung oleh proses pencernaan yang cepat sehingga ibu memiliki kekuatan lebih untuk mengejan dan perasaan lebih tenang selama menghadapi persalinan sehingga mendukung proses kemajuan selama kala II.

Kurma selain mengandung sumber gula yang tinggi juga dapat memberikan perasaan rileks dan tenang. Asam lemak pada kurma selain menghasilkan energi juga membantu 
menyediakan prostagalndin sehingga dapat membantu menyimpan energi serta memperkuat otot rahim.

Menurut pendapat Cashion, Perry, Lowdermilk dkk (2013) Salah satu faktor yang mempengaruhi proses persalinan adalah power. Kekuatan berasal dari perubahan fisiologis ibu bersalin itu sendiri dan dari tenaga meneran ibu. Seorang ibu bersalin memerlukan tenaga meneran yang kuat untuk membantu memperlancar proses persalinannya.

Hal ini sesuai dengan pernyataan oleh Kordi et.al (2014) dalam penelitiaannya menunjukkan bahwa kurma kaya akan karbohidrat sebagai sumber tenaga, mempengaruhi kemajuan persalinan, spontanitas dalam persalinan dikarenakan karbohidrat yang terdapat dalam kurma sebagai penguat ini adalah gula yang diserap dan digunakan oleh sel tubuh tidak lama setelah dikonsumsi.

Proses kemajuan kala II selain dipengaruhi oleh faktor tenaga juga didukung oleh faktor psikologi, penolong persalinan, jalan lahir yang normal serta posisi atau letak janin serta plasenta yang normal.

\section{Kemajuan Persalinan Kala II Ibu Bersalin Yang Tanpa Diberi Kurma Di Rumah Sakit Aura Syifa Kabupaten Kediri}

Berdasarkan data yang
diperoleh bahwa sebanyak 16 responden ibu bersalin tanpa diberikan kurma didapatkan 13 responden $(81,25 \%)$ ibu bersalin mengalami kemajuan persalinan normal dan 3 responden $(18,75 \%)$ ibu bersalin mengalami kemajuan persalinan tidak normal.

Menurut (Cunningham, 2005) usia merupakan salah satu faktor risiko yang berhubungan dengan kualitas kehamilan atau berkaitan dengan kesiapan ibu dalam reproduksi. Usia kurang dari 20 tahun rahim dan panggul belum tubuh mencapai ukuran dewasa. Akibatnya apabila ibu hamil pada usia ini mungkin mengalami persalinan lama atau macet. Didapatkan hasil bahwa terdapat 1 responden $(6,25 \%)$ berusia kurang dari 20 tahun pada kelompok kontrol, dan 3 responden $(18,75)$ pada kelompok intervensi.

Hal ini juga didukung oleh hasil food recall yang dilakukan oleh enumerator RS Aura Syifa pada ibu bersalin yang bertujuan untuk mengetahui seberapa banyak asupan makanan yang dikonsumsi ibu selama persalinan. Sehingga dapat diketahui bahwa asupan makanan serta status gizi yang diperoleh ibu dalam batas normal atau tidak. Setelah dilakukan perhitungan dengan hasil food recall yang telah diperoleh, diketahui terdapat ibu bersalin sebanyak 3 responden $(18,75)$ diketahui memiliki status gizi dengan kategori kurang yakni < 80. Dengan hasil status gizi yang kurang dapat disimpulkan bahwa asupan makanan ibu yang dikonsumsi sedikit, hal ini diketahui bahwa kebutuhan kalori ibu tidak sebanding dengan asupan konsumsi sehingga energi yang dimiliki hanya sedikit.

Pada kelompok kontrol diketahui sebanyak 13 responden $(81,25 \%)$ mengalami kemajuan persalinan normal, hal ini didukung oleh hasil food recall yang diketahui bahwa responden tersebut memiliki status gizi yang baik sebanyak 12 responden (75 \%) dan status gizi lebih sebanyak 1 responden $(6,25 \%)$. Sehingga dapat disimpulkan bahwa ibu dengan status gizi yang baik bahkan lebih memiliki kecukupan energi untuk menghadapi proses persalinan. Diketahui bahwa kala II merupakan proses yang lebih berat dibandingkan dengan kala I.

Pada saat penelitian banyak ibu mengatakan bahwa ibu merasa lelah 
dan tidak kuat untuk mengejan saat proses kala II, akan tetapi dengan adanya cadangan energi yang baik dan ada pada ibu serta dukungan dan kerja sama dari pihak keluarga, ibu serta penolong dapat membuat ibu tetap termotivasi melakukan sekuat tenaga untuk mengejan.

Penelitian (Kumarawati, 2010) kemajuan kala I fase aktif merupakan saat yang paling berat, melelahkan dan kebanyakan ibu mulai merasakan sakit atau nyeri hebat karena kegiatan rahim mulai aktif, sehingga dibutuhkan kekuatan yang adekuat untuk memulai persalinan.

Perempuan yang akan melahirkan sangat membutuhkan asupan energi yang kaya akan unsur gula, karena banyaknya kontraksi otototot rahim ketika akan mengeluarkan bayi, terlebih apabila itu membutuhkan waktu yang lama. Hal ini tentunya juga didukung oleh banyak faktor diantaranya adalah waktu yang lama selama proses persalinan dan kekuatan ibu yang lemah dikarenakan oleh faktor usia, konsumsi gizi yang rendah kalori serta menjadikan tenaga ibu habis, faktor lainnya adalah perasaan takut, nyeri kecemasan dan rasa tidak aman yang dirasakan dilingkungan dan orang baru disekitarnya dapat memicu gangguan kemajuan persalinan. Hal ini juga dapat menimbulkan stres pada ibu, akibatnya terjadi pengeluaran adrenalin sehingga pembuluh darah menyempit dan mengurangi aliran darah yang membawa oksigen ke rahim. Akibatnya, terjadi penurunan kontraksi rahim yang memanjang pada waktu persalinan (Padila, 2014).

\section{Pengaruh Pemberian Kurma Terhadap Kemajuan Persalinan Kala II Ibu Bersalin Di Rumah Sakit Aura Syifa Kabupaten Kediri}

Berdasarkan hasil Uji Fisher Exact Probability Test di dapatkan hasil $\rho$-value sebesar 0,1129 dengan taraf signifikasi (a) 0,05 sehingga $\rho$ hitung > a maka $\mathrm{H}_{1}$ ditolak dan $\mathrm{H}_{0}$ diterima (Tidak ada pengaruh pemberian kurma terhadap kemajuan Persalinan Kala II ibu Bersalin di Rumah Sakit Aura Syifa Kabupaten Kediri).

Menurut (Saifuddin, A,B, 2009) menjelaskan bahwa kala II persalinan dimulai ketika pembukaan serviks sudah lengkap yakni pada pembukaan $10 \mathrm{~cm}$ sampai dengan lahirnya bayi atau disebut dengan kala pengeluaran. Berlangsung selama 2 jam pada primigravidan dan 1 jam pada multigravida. Dimana proses kemajuan persalinan menjadi lama dikarenakan dipengaruhi oleh berapa faktor diantaranya: usia ibu, pengetahuan mengenai proses persalinan dan tingkat pendidikan, kemudian dipengaruhi oleh pengaruh psikologi ibu seperti tidak adanya dukungan dari kelaurga ataupun suami dikarenakan suami bekerja diluar daerah tempat tinggalnya dan ibu jauh dari kelurga sehingga tidak adanya dukungan dari orang-orang terdekatnya.

Menurut (Padila, 2014) sebagian wanita yang tidak memiliki pengetahuan dan kesiapan dalam menghadapi proses persalinan akan kehilangan kendali sehingga menunjukkan perilaku seperti menangis atau gerkaan tidak terkendali saat ditempat tidur. Akibat dari persiapan ibu yang kurang, menjadikan ibu sanagt takut menghadapi proses persalinan.

(Satuhu, 2010) menjelaskan bahwa kurma memiliki manfaat seperti mengurangi ketegangan mental dan histeria. Hal ini sangat bermanfaat bagi ibu yang akan melahirkan agar tetap tenang sehingga mengurangi risiko terjadinya perdarahan dalam rahim. Penyerapan kurma dalam tubuh lebih cepat apabila dibandingkan dengan 
daya absorbsi pati nasi yang memerlukan waktu berjam-jam sehingga kurma merupakan makanan yang sangat baik karena dapat menyuplai energi secara cepat.

Selain faktor-faktor tersebut faktor lainnya kemungkinan adalah faktor "flat slop sindrom" yaitu pada saat food recall ibu melaporkan makanannya sedikit walaupun sesungguhnya makannya banyak atau sebaliknya. Atau mungkin juga dipengaruhi "lupa" karena ibu hamil harus mengingat makanan 24 jam yang lalu. Selain itu, faktor kesalahan lainnya adalah dari enumerator. Enumerator sulit untuk mengarahkan subjek untuk mengingat makanannya.

Pada penelitian ini diketahui bahwa hasil $\rho$ value sebesar 0,1129 dengan taraf signifikasi (a) 0,05 sehingga $\rho$ hitung $>$ a maka $\mathrm{H}_{1}$ ditolak dan $\mathrm{H}_{0}$ diterima (Tidak ada pengaruh pemberian kurma terhadap kemajuan Persalinan Kala II ibu Bersalin di Rumah Sakit Aura Syifa Kabupaten Kediri).

Hal ini dikarenakan pemberian kurma yang hanya diberikan dalam satu waktu, sehingga manfaat yang diperoleh hanya pada cadangan tenaga sebagai tambahan kalori ibu menjelang persalinan. Akan tetapi tidak menimbulkan pengaruh pada kemajuan persalinan. Selain it terdapat faktor bias yang sulit untuk dibuktikan secara empiris bahwa memang karena pemberian kurma kemajuan persalinan kala II menjadi normal.

\section{KESIMPULAN}

Berdasarkan analisis hasil dan pembahasan tersebut maka dapat diambil kesimpulan (1) Ibu bersalin kala II yang diberikan kurma di Rumah Sakit Aura Syifa mengalami kemajuan normal sebesar (100 \%); (2) Ibu bersalin kala II yang tanpa diberi kurma di Rumah Sakit Aura Syifa mengalami kemajuan normal sebesar $(81,25 \%)$; (3) Tidak ada pengaruh pemberian kurma terhadap kemajuan persalinan kala II ibu bersalin di Rumah Sakit Aura Syifa Kabupaten Kediri.

\section{DAFTAR PUSTAKA}

Badwilan, A.S. 2008. The Miracle of Dates Rahasia Sehat Alami Dengan Kurma

Budiarto, E. 2001. Biostatistika Untuk Kedokteran dan Kesehatan Masyarakat. Jakarta : EGC

Cashion, Perry, Lowdermilk. 2013. Keperawatan Maternitas Edisi 8. Singapore: Elsevier Morby.

Cahyo. 2011. Penjelasan-penjelasan Ilmiah Tentang Dahsyatnya Manfaat Ibadah-ibadah Harian Untuk Kesehatan Jiwa Dan Fisik Kita. Yogyakarta: Diva Press

Cunningham, F.G. 2005. Obstetri Williams. Jakarta : EGC

Djarwanto. 2009. Statistik Nonparametrik. Yogyakarta : BPFE

Depkes RI. 2008. Asuhan Persalinan Normal \& Inisisasi Menyusu Dini. Jakarta : JNPK-KR

Dinas Kesehatan Kabupaten Kediri. 2014. Profil Kesehatan Kabupaten Kediri.

Erawati, A. D. 2010. Buku Ajar Asuhan Kebidanan Persalinan Normal. Jakarta : EGC

Hardjito, Koekoeh. 2012. Pengantar Biostatistika. : Forikes

Hidayat, A.A. 2010. Metode Penelitian Kebidanan \& Teknik Analisis Data. Jakarta : Salemba Medika

Holmes, D \& Baker, N. 2011. Buku Ajar Ilmu Kebidanan. Jakarta: EGC

Kementerian Kesehatan RI. 2015. Buku Ajar Kesehatan Ibu Dan Anak. Jakarta:Kementerian Kesehatan RI 
Kordi, M. et.al., 2014. The Effect of Late-Pregnancy Consumption of Date Fruit on Cervical Ripening in Nulliparaous Women. Journal of Midwifery \& Reproductive Health, 2(3), pp.151-156.

Kumarawati, E. 2010. Pengaruh Pemberian Pocari Sweat Terhadap Kualitas His Persalinan. http://isjd.pdii.lipi.go.id/admin/j urnal /11102529.pdf

Manuaba, dkk. 2008. Buku Ajar Patologi Obstetri untuk Mahasiswa Kebidanan. Jakarta : EGC

Nazir. 2009. Metode Penelitian. Bogor : Ghalia Indonesia

Notoatmodjo, S. 2012. Metodologi Penelitian Kesehatan. Jakarta : Rineka Cipta

Nugraheni, dkk. 2015. Pengaruh Pemerian Buah Kurma Kering (Tamr) Mulai Usia Kehamilan 37 minggu terhadap Kemajuan Proses Persalinan Pada Ibu Bersalin. Di akses pada tanggal 09 Februari 2017

Nursalam. 2013. Metodologi Penelitian IImu Keperawatan: Pendekatan Praktis. Jakarta : Salemba Medika

Oxorn, H \& Forte, W. R. 2010. IImu Kebidanan Patologi dan Fisiologi Persalinan. Yogyakarta : Yayasan Essentia Medika

Padila. 2014. Buku Ajar Keperawatan Maternitas. Yogyakarta : Nuha Medika

Prawirohardjo, S. $2014 . \quad$ IImu Kebidanan. Jakarta : Bina Pustaka

Rahmawan, Zaki. 2005. Kupas Tuntas Khasiat Kurma Berdasarkan AlQur'an Al-Karim, As-Sunnah Ash-Shahihah dan Tinjauan Medis Modern. Bogor: Media Tarbiyah.

https://almanhaj.or.id/2228- manfaat-buah-kurma-menurutsudut-pandang-medismodern.html

Rinanto. 2015. Keajaiban Resep Obat Nabi S.A.W. Jakarta : Qisthi Press

Rohani, dkk. 2013. Asuhan Kebidanan Pada Masa Persalinan. Jakarta : Salemba Medika

Saifuddin, A, B. 2009. Buku Acuan Nasional Pelayanan Kesehatan Maternal dan Neonatal. Jakarta : YBPSP

Saryono. et.al.,2016. Effects Of Dates Fruit (Phoenix Dactylifera L.) In The Female Reproductive Process. International Journal of Recent Advances in Multidisciplinary Research, 3(7), pp.1630-1633.

Satuhu, S. 2010. Kurma Khasiat Dan Aneka Olahannya. Jakarta : Penebar Swadaya

Sediaoetama. A.D. 2010. Ilmu Gizi Untuk Mahasiswa dan Profesi. Jakarta : Dian Rakyat

Siregar, M. H. 2012. Cara Sehat dengan Resep-resep Ajaib Herbal Islami. Yogyakarta : Buku Biru

Soebahar, dkk. 2015. Mengungkap Rahasia Buah Kurma dan Zaitun. Diakses pada tanggal 09 Februari 2017

Sugiyono. 2015. Metode Penelitian Kuantitatif Kualitatif dan $R \& D$. Bandung : Alfabeta

Sulistyawati, A \& Nugraheny, E. 2013. Asuhan Kebidanan Pada Masa Kehamilan. Jakarta : Salemba Medika.

Supariasa, dkk. 2012. Penilaian Status Gizi. Jakarta : EGC

Susilo, W. H. 2012. Statistika \& Aplikasi Untuk Penelitian IImu Kesehatan. Jakarta : Trans Info Media

USDA National Nutrient Database for Standard Reference Release 28 
Received: 19 Januari 2020 :: Accepted: 11 Februari 2020 :: Publish: 30 April 2020

slightly revised May, 2016 Basic

Report February 22, 2017 09:52

WHO. 2013. Buku Saku Pelayanan

Kesehatan Ibu di Fasilitas

Kesehatan Dasar dan Rujukan.

Jakarta: WHO. 